\section{Overhead and Drip Irrigation System Effects on Tomato Growth and Yield in California's Central Valley}

\author{
Jeffrey P. Mitchell ${ }^{1,5}$, Anil Shrestha ${ }^{2}$, Karen Klonsky ${ }^{3}$, \\ Tom A. Turini ${ }^{4}$, and Kurt J. Hembree ${ }^{4}$
}

AdDITIONAL INDEX WORDS. center pivot irrigation, controlled traffic farming, notillage, Solanum lycopersicum

SUMMARY. Despite the worldwide importance of overhead, mechanized irrigation for crop production, the potential of this technology has been poorly studied in California. Field studies were conducted at Five Points, CA, in 2010 and 2012 to compare the effects of overhead irrigation $(\mathrm{OH})$ and drip irrigation $(\mathrm{DR})$ on transplanted tomato (Solanum lycopersicum) crop growth and yield. Similar amounts of water were applied to both systems in each year to match crop evapotranspiration demands. Crop growth measured by percent canopy coverage and aboveground biomass accumulation were similar between the $\mathrm{OH}$ and DR systems early in the growing season in both years but were lower in the $\mathrm{OH}$ system during the second half of each season. Tomato yield was 38\% greater in 2012 than in 2010 and averaged over the 2 years, $48 \%$ higher in the DR than in the $\mathrm{OH}$ systems, respectively, due presumably to the higher soil water evaporation losses of the $\mathrm{OH}$ system relative to the DR system and also, we propose, to the ability of the drip system to very precisely apply in-season fertigations directly to the crop root zone while $\mathrm{OH}$ fertigations were applied at the soil surface and over a greater area. Soluble solids concentration of fruit in 2010 was $\mathbf{5 . 9 9 \%}$ for the DR system and $6.65 \%$ for the $\mathrm{OH}$ system providing further evidence of water stress in the $\mathrm{OH}$ tomatoes. Production costs associated with transitioning from a subsurface drip tomato crop to a sprinkler or surface drip-irrigated crop such as onion (Allium cepa) or garlic (Allium sativum) could be $\$ 130$ to $\$ 420$ per acre lower with the $\mathrm{OH}$ system compared with the drip system, if yields were maintained. Because operation and labor costs of $\mathrm{OH}$ systems are typically lower than those of DR systems, further research on $\mathrm{OH}$ irrigation of tomato is warranted to address the shortcomings of $\mathrm{OH}$ management that this study has identified.

$\mathrm{P}$ rocessing tomato production in California is one of the state's agricultural success stories accounting for $96 \%$ of U.S. production in recent years [U.S. Department of Agriculture (USDA), 2014]. Since the advent of recordkeeping and the shift of production from the eastern United States throughout the 20th century (Geisseler and Horwath, 2013),

We thank Jaime Solorio, Merph Solorio, Tracy Waltrip, and Nelson Vallejo of the University of California West Side Research and Extension Center in Five Points, CA, for their assistance in this work.

${ }^{1}$ Department of Plant Sciences, University of California, Davis, 9240 S. Riverbend Avenue, Parlier, CA 93648

${ }^{2}$ Department of Plant Science, California State University, Fresno, 2415 E. San Ramon Avenue M/S AS 72, Fresno, CA 93740

${ }^{3}$ Department of Agricultural and Natural Resource Economics, University of California, Davis, CA 95616

${ }^{4}$ University of California Cooperative Extension, Fresno County, 550 E. Shaw Avenue, Suite 210-B, Fresno, CA 93710

${ }^{5}$ Corresponding author. E-mail: jpmitchell@ucdavis. edu. processing tomato yields in California have increased $742 \%$ due in part to technological advances achieved in harvesting equipment, irrigation management, and variety development (Hanson and May, 2006; Mitchell et al., 2012).

Current production techniques throughout California's Central Valley $(\mathrm{CV})$, where most tomato production occurs, rely increasingly on the use of transplants for stand establishment (Hartz et al., 2008), permanent subsurface drip tape for irrigation (Mitchell et al., 2012), and numerous intercrop tillage operations that are routinely performed for residue, and salinity management, and also to mix herbicide residues throughout the soil so they do not accumulate in certain zones of semi or permanent bed production systems (Mitchell et al., 2009, 2012). Advantages from DR include higher yields than with surface or sprinkler irrigation and thus account for the widespread and growing use of DR for tomatoes in the CV (Hanson and May, 2006). However, the main disadvantage of DR is its initial capital cost (Hanson and May, 2006) as well as ongoing costs associated with maintenance. In recent years, there is also a growing trend of coupling subsurface DR with 80 -inch beds to increase land-use efficiency and this has resulted in further yield increases.

Much is known about optimal irrigation for high yields and soluble solids' content of processing tomato (Hanson and May, 2005, 2006; Phene et al., 1985). The basic equation is now widely used by $\mathrm{CV}$ tomato farmers for irrigation scheduling is $\mathrm{ETc}=\mathrm{Kc} \times \mathrm{ETo}$, where ETc is the projected evapotranspiration of the tomato crop, $\mathrm{Kc}$ is a corresponding growth-stage-dependent crop coefficient, and ETo is reference evapotranspiration for a given production region (Hanson and May, 2005, 2006). Extensive work by Hanson and May (2006) determined the relationship between irrigation crop coefficients and canopy coverage and suggested using a crop coefficient of 0.19 for canopy coverage less than $10 \%$, an average midgrowth stage crop coefficient

\begin{tabular}{lllc}
\hline $\begin{array}{l}\text { Units } \\
\begin{array}{l}\text { To convert U.S. to SI, } \\
\text { multiply by }\end{array}\end{array}$ & U.S. unit & SI unit & $\begin{array}{l}\text { To convert SI to U.S., } \\
\text { multiply by }\end{array}$ \\
\hline 0.4047 & $\mathrm{acre}(\mathrm{s})$ & $\mathrm{ha}$ & 2.4711 \\
0.3048 & $\mathrm{ft}$ & $\mathrm{m}$ & 3.2808 \\
0.0929 & $\mathrm{ft}^{2}$ & $\mathrm{~m}^{2}$ & 10.7639 \\
3.7854 & $\mathrm{gal}$ & $\mathrm{L}$ & 0.2642 \\
9.3540 & $\mathrm{gal} / \mathrm{acre}$ & $\mathrm{L} \cdot \mathrm{ha}^{-1}$ & 0.1069 \\
2.54 & inch $(\mathrm{es})$ & $\mathrm{cm}$ & 0.3937 \\
0.4536 & $\mathrm{lb}$ & $\mathrm{kg}$ & 2.2046 \\
1.1209 & $\mathrm{lb} / \mathrm{acre}$ & $\mathrm{kg} \cdot \mathrm{ha}^{-1}$ & 0.8922 \\
0.0254 & $\mathrm{mil}$ & $\mathrm{mm}$ & 39.3701 \\
28.3495 & $\mathrm{oz}$ & $\mathrm{g}$ & 0.0353 \\
305.1517 & $\mathrm{oz} / \mathrm{ft}^{2}$ & $\mathrm{~g} \cdot \mathrm{m}^{-2}$ & 0.0033 \\
0.9072 & ton $(\mathrm{s})$ & $\mathrm{Mg}$ & 1.1023 \\
2.2417 & ton $(\mathrm{s}) / \mathrm{acre}$ & $\mathrm{Mg} \cdot \mathrm{ha}^{-1}$ & 0.4461 \\
$\left({ }^{\circ} \mathrm{F}-32\right) \div 1.8$ & ${ }^{\circ} \mathrm{F}$ & ${ }^{\circ} \mathrm{C}$ & $\left({ }^{\circ} \mathrm{C} \times 1.8\right)+32$
\end{tabular}

Hortlechnology · December $201424(6)$ 
between 0.99 and 1.08 , with a latecrop growth reduction or irrigation cutback to improve crop quality. An advantage of DR relative to the former industry standard furrow irrigation has been the ability to precisely apply small amounts of water more frequently to maintain these ETc targets.

Overhead irrigation, including both center pivot and linear move systems, is a technology that is important for a wide range of crops and regions throughout the United States and many parts of the world but is currently not widely used in California. In this article, we use the term $\mathrm{OH}$ to denote both center pivot and linear move systems. Though pivots tend to cost less than linear systems to install, the operation and irrigation management for these two $\mathrm{OH}$ systems are similar. In recent years, Nebraska and California are the top two U.S. states in total irrigated acres, with 8.6 million and 8.0 million acres, respectively. Nebraska has an estimated 75,000 pivots in operation, but there are fewer than 350 in California (Johnson et al., 2011; USDA, 2007). Overhead irrigation may have a number of advantages that could conceivably be important for $\mathrm{CV}$ tomato farmers in terms of reducing production costs as a potentially cheaper production system alternative to DR, and also for maintaining fruit yields and quality under the State's increasingly water-short conditions (Pelter and Sorensen, 2003). However, researchbased information is needed to compare these systems in terms of their overall production costs and water-use efficiency. To date, there were a few commercial attempts in the CV to use $\mathrm{OH}$ for tomato production in the 1990 s and another more recent effort in 2009. However, for a number of reasons including inability of the $\mathrm{OH}$ system to keep up with ETc demands in the 1990s instances and logistical issues related to water availability to the field in the 2009 attempt, these efforts were not economically successful and have been abandoned.

In many regions where $\mathrm{OH}$ technologies are used, they are commonly coupled with reduced tillage planting techniques in large part to further lower productions costs, but also because with $\mathrm{OH}$ customary planting, beds and furrows are no longer necessary as they are in surface irrigation systems. Because no studies in the CV have been published on the use of $\mathrm{OH}$, there is a need to compare the performance and profitability of this practice with local standard subsurface DR minimum tillage (MT) production practices, to evaluate the potential for using pivot irrigation for an economically important crop such as tomato, and to provide best management guidance to farmers who may seek to use it. Therefore, the objective of this study was to compare crop growth and yield of tomato under DR and $\mathrm{OH}$ using $\mathrm{MT}$.

\section{Materials and methods}

A 2-year (2010 and 2012) field study was conducted at the University of California's West Side Research and Extension Center (WSREC) in Five Points, CA (lat. $36.341389^{\circ} \mathrm{N}$, long. $\left.120.120556^{\circ} \mathrm{W}\right)$. The experimental area was 8.8 acres with 256 five-foot-wide beds with a row length of $300 \mathrm{ft}$. The soil type was Panoche clay loam (fine-loamy, mixed superlative, thermic Typic Haplocambids) (Arroues, 2006). The studies were part of a 4-year vegetable crop rotation [tomato (2010)-onion (2010-11)broccoli (Brassica oleracea var. italica) (2011)-tomato (2012)-onion (2013)broccoli (2014)]. The experimental design was a randomized complete block with irrigation types as treatment. A uniform wheat (Triticum aestivum) crop was grown in the experimental field during Winter 2009-10 in an attempt to create uniform initial water and fertility conditions throughout the field. The irrigation systems were maintained similarly for all the crops in the entire rotation. The MT consisted of standard tillage operations including disking, ripping to a depth of 18 inches, bed listing, and cultimulching (Mitchell et al., 2012) at the start of the study in 2010 and two intercrop preplant tillage passes using a bed reworking implement (Performer; Wilcox Agriproducts, Walnut Grove, CA) that was fitted with chisel-point shanks set at about 9 inches deep to loosen soil on the shoulders of beds, a rolling rotor blade to chop and mix residues, and a shaping shroud to form beds for the 2012 crop. The experimental design was a randomized complete block with four replications of each irrigation type. Because the 2010 tomato crop was the first crop in the rotation, slightly different pretransplant tillage was used in the 2 years. Controlled traffic was used throughout the study in all the plots, which meant that only certain furrow areas were trafficked while the tomato crop growth zones or beds were not trafficked. Each $300-\mathrm{ft}$ plot consisted of 15 beds with 60 inches between the middle of one bed and the middle of the next bed. Buffer zones of at least three beds on either side of the plots were maintained. Only the central nine beds were used for data collection.

Locally common processing tomato varieties, $\mathrm{AB} 2$ (Monsanto, St. Louis, MO) in 2010, and N6397 (Nunhems USA, Parma, ID) in 2012, were mechanically transplanted at 12 inch in-row spacing in a single plant line per bed with a target of 8700 plants/acre. These varieties are known to be similar in their general growth and irrigation requirements, while $\mathrm{N}$ 6397 is earlier maturing than AB2. Harvest would be earlier and irrigation amount would thus be less (E. Miyao, personal communication). Associated with the three-bed transplanter to help with seedling establishment, 2000 gal of transplant water were combined with $3 \mathrm{gal} / \mathrm{acre}$ of a $3 \mathrm{~N}-83.5 \mathrm{P}-3.7 \mathrm{~K}$ liquid starter fertilizer (Transplant Supreme; Crop Production Services, Fresno, CA) and applied on 22 Apr. 2010 and 30 Apr. 2012. Transplants in all plots were initially irrigated four times using a hose-fed lateral-move $\mathrm{OH}$ system (model 6000; Valmont Irrigation, Valley, NE) with eight 150 -ft-wide spans for establishment. The area under each span of the $\mathrm{OH}$ system was considered a main plot. After the seedlings were established, the $\mathrm{OH}$ system was only used in the $\mathrm{OH}$ plots and not the DR plots. "Bubbler" nozzles that dribble water in a narrow stream were used from transplant establishment through the early vegetative growth phase in both years in an effort to apply water directly to the plants and thereby minimize soil water evaporation (Fig. 1). The $\mathrm{OH}$ system was then fitted with rotatortype nozzles (Nelson Irrigation, Walla Walla, WA) with $360^{\circ}$ random rainfall spray patterns to increase the wetted volume across the beds. At the edges of the split plots, $180^{\circ}$ center-facing nozzles were used to prevent overspray with the DR system. Once fruit began to size and mature, the $360^{\circ}$ nozzles were replaced with bubbler 
A.

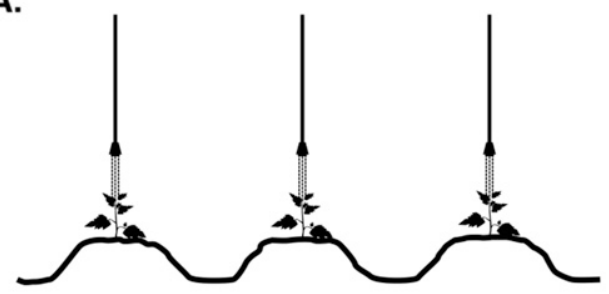

B.

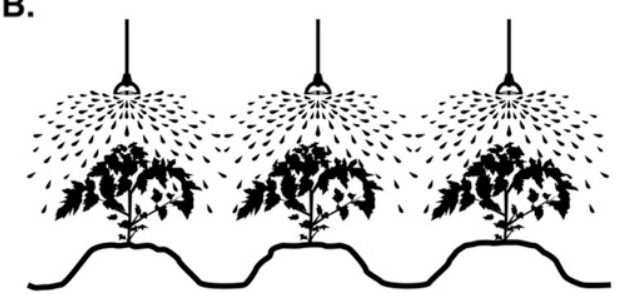

c.

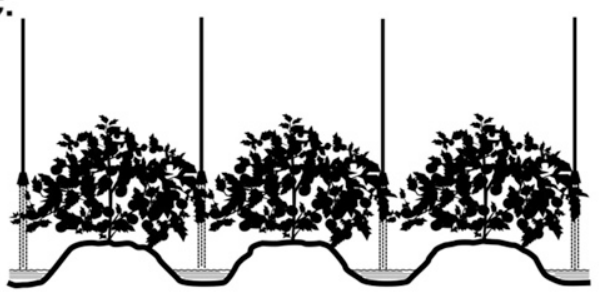

Fig. 1. Schematic representation of overhead irrigation application methods and locations of application devices for (A) early season, (B) midseason, and (C) lateseason tomato production at Five Points, CA, in 2010 and 2012.

nozzles repositioned in the furrow areas and used until irrigation cutoff before harvest to avoid the potential of rotting fruit due to direct spray of the rotator $\mathrm{OH}$ nozzles (Fig. 1). Irrigation applications for the $\mathrm{OH}$ systems were determined by a combination of the lateral-move system speed and application nozzle flow rates while an in-line flow meter (Seametrics, Kent, WA) measured the output.

The subsurface DR system used a single line of 0.37 -gal $/ \mathrm{h} 7 / 8$-inch i.d. with 12 -inch in-line spacing DR tape installed at 12 -inch depth in the center of each bed. Water application volumes were monitored using an inline flow meter (McCrometer, Hemet, CA). Irrigation application schedules for both the DR and $\mathrm{OH}$ systems were determined using ETo data from a California Irrigation Management Information System (CIMIS, 2012) weather station located about 50 yards from the study field. Crop coefficient values were based on crop canopy estimates for each irrigation plot.

The herbicide, trifluralin, was pretransplant applied at $1.5 \mathrm{lb} /$ acre a.i. by ground spray rig in both years and sprinkler incorporated. Paraquat (Gramoxone Inteon; Syngenta Crop
Protection, Wilmington, DE) at $\mathrm{l} \mathrm{lb} /$ acre a.i. was applied pretransplant to the NT plots on 25 Apr. 2012 and sethoxydim (Poast; Bayer CropScience, Leverkusen, Germany) was applied posttransplant at $0.28 \mathrm{lb} /$ acre a.i. on 11 May 2012.

Hand weeding and mechanical cultivation using a three-row 60 -inch high-speed row crop cultivator $(9400$; Sukup Manufacturing, Sheffield, IA) were also done in all systems and preplant fertilizer $(11 \mathrm{~N}-22.7 \mathrm{P}-0 \mathrm{~K})$ at $150 \mathrm{lb} /$ acre was shank-applied to all plots in both years. Weekly fertigation applications of urea and ammonium nitrate (UAN32) totaling 170 and $190 \mathrm{lb} /$ acre nitrogen were made in 2010 and 2012, respectively from mid-May through late July to both the DR and $\mathrm{OH}$ systems.

Similar amounts of water were applied to the $\mathrm{OH}$ and DR treatments within each year, but $\approx 20 \%$ more water was applied in 2012 in an attempt to address the fact that no preirrigation had been applied to fill the soil profile as is customarily done in commercial fields. (Fig. 2A and B). The higher application volumes in 2012 also more closely represented actual grower practices for processing tomatoes in the region that year (S. Schmidt, personal communication). These irrigation applications also closely matched ETc estimates in both years. Estimated ETc values and applied water amounts were slightly lower than published average seasonal values in 2010 and slightly above historical averages in 2012 (Hanson and May, 2006). Canopy coverage, expressed as the percent of the soil area shaded by the canopy at midday, was determined each year from images taken roughly every other day at four locations within each plot with a digital IR camera (Dycam, Woodland Hills, CA) positioned about $6 \mathrm{ft}$ above the ground surface (Hanson and May, 2006). Tomato biomass dry weight and fruit fresh weight were determined in 2010 by taking a random sample in each plot on 7 July 2010. Plants within a $0.45-\mathrm{m}^{2}$ area in each plot were clipped at the soil surface, put into paper bags, dried in a forcedair oven at $70{ }^{\circ} \mathrm{C}$ for $72 \mathrm{~h}$, and their dry weights were recorded. In 2012, plant weights were more intensively sampled by taking a random sample of four plants per plot 15 times throughout the season. Tomato fruit were separated from vegetative stem and leaf weights on four sampling dates in July and August. Tomatoes were harvested in both years using commercial mechanical harvesters and yields were determined using gondola trailers equipped with electronic scales. Data on tomato fruit quality parameters, soluble solids, color, and $\mathrm{pH}$ were determined by a commercial grading station from roughly 50 -lb fruit subsamples from each plot collected from the harvester in 2010

Economic budget data were obtained from published University of California Cooperative Extension production cost studies (Stoddard et al., 2006; Takele et al., 2013; Tourte and Smith, 2010; Wilson et al., 2011) and also from surveys of five CV farmers to estimate irrigation costs associated with installing and removing sprinkler pipe for crop germination and establishment and for installing and removing thinwalled (6 to 8 mil) surface drip tape as would be required when rotating from a subsurface-irrigated crop such as tomato, to a common $\mathrm{CV}$ rotation crop such as onion or garlic, for which surface or near-surface ( 2 to 3 inches below the soil surface) placed tape is used.

Data were subjected to analysis of variance (ANOVA) using SAS (version 
9.2; SAS Institute, Cary, NC). Assumptions of ANOVA were checked by testing for normality and homogeneity of variance. Data were logtransformed to meet the assumptions of ANOVA and analyses were conducted on transformed data. Mean separations were based on transformed data, but nontransformed means were reported for ease in presentation. Data for yield were $\log 10$ transformed. Year was considered a random factor and irrigation type the fixed factor. Interaction between year and treatment was tested and where it was not significant data were combined for the 2 years or else each year was analyzed separately. Since different samples were taken at each time, data for each sampling data were analyzed separately. The generalized linear model procedures were used at a significance level of 0.05 to examine differences between years, irrigation treatments, and interactions between years and irrigation treatments. Replications and years were considered as random effects and irrigation treatments as fixed effects. There was no interaction between year and irrigation (Table 1). Therefore, the data for the 2 years were combined and analyzed.

\section{Results and discussion}

In each year of the study, both the DR and the $\mathrm{OH}$ systems were able to apply precise, small amounts of water frequently that have been shown to be required for high tomato yields (Hanson et al., 2003; Phene, 2010) (Fig. 2). In 2010, the $\mathrm{OH}$ was irrigated 42 times and the DR system was irrigated 43 times, while in 2012 , 46 and 48 applications were made for the $\mathrm{OH}$ and DR systems, respectively.

Digital IR camera-derived percent canopy cover estimates as indicators of tomato growth followed similar patterns in both years of the study (Fig. 3). Canopy coverage of the tomato plants in the $\mathrm{DR}$ and $\mathrm{OH}$ systems was similar during the early season; however, it tended to be higher in the DR system throughout the latter two-thirds of the season, particularly in 2010. Samples taken on 7 July 2010 showed that the plant dry weight was greater in the DR than in the $\mathrm{OH}$ systems (Fig. 4), which supported the canopy coverage data (Fig. 3), but the fresh weight of the fruits was similar $(P=0.17)$ between the two systems $\left(85\right.$ and $96 \mathrm{~g} \cdot \mathrm{m}^{-2}$ in

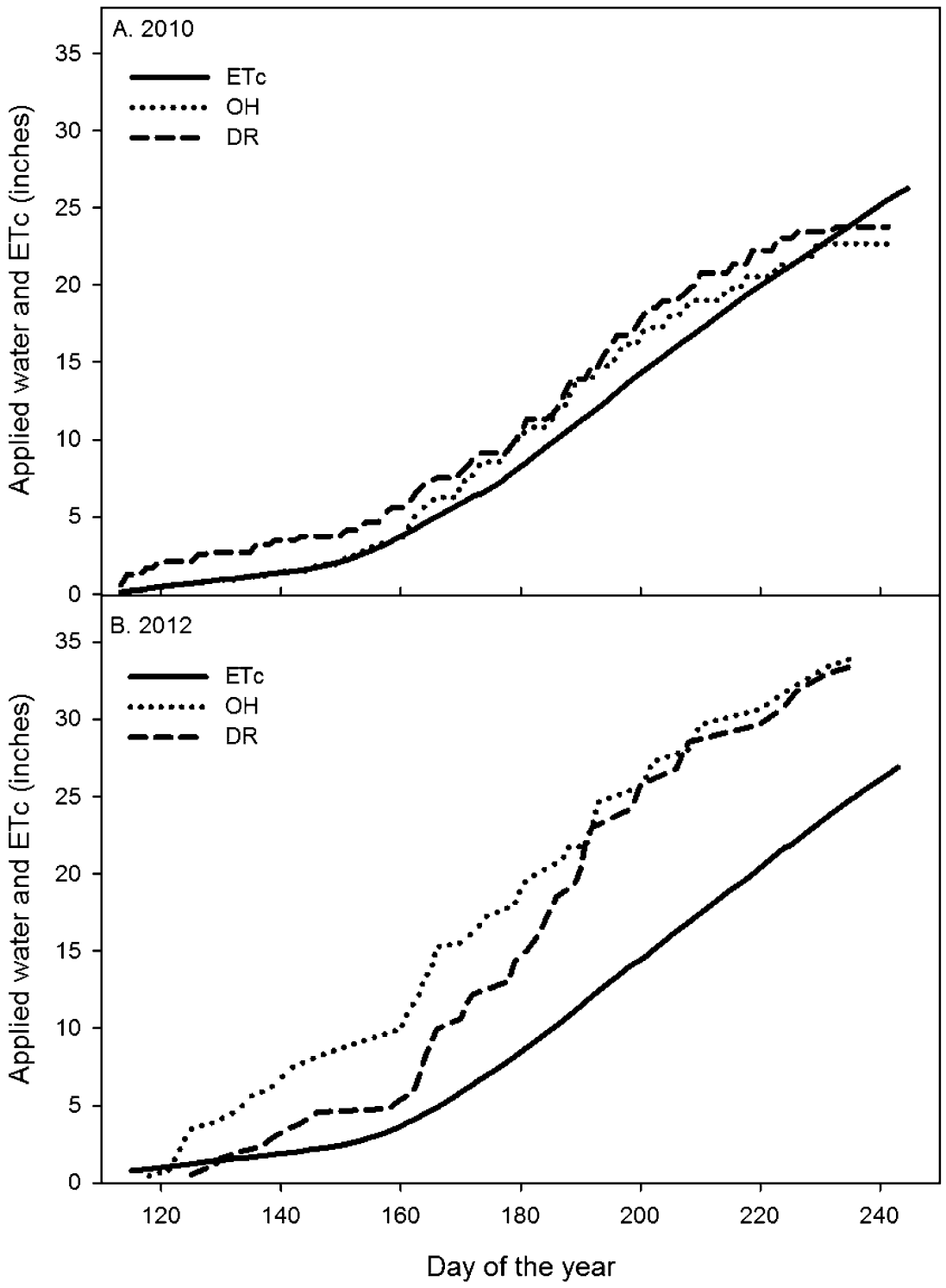

Fig. 2. Cumulative applied water and estimated crop evapotranspiration (ETc) for drip (DR) and overhead $(\mathrm{OH})$ tomato irrigation systems at Five Points, CA, in (A) 2010 and $(B) 2012 ; 1$ inch $=2.54 \mathrm{~cm}$.

Table 1. Drip irrigation system cost estimates per acre to transition from a subsurface drip-irrigated tomato crop to a surface drip-irrigated crop such as onion or garlic in the San Joaquin Valley.

\begin{tabular}{lcc}
\hline & \multicolumn{2}{c}{ Costs and labor costs $(\$ / \text { acre })^{\mathrm{z}}$} \\
\cline { 2 - 3 } Operation & $\begin{array}{c}\text { Published } \\
\text { cost estimates }\end{array}$ & $\begin{array}{c}\text { Farmer survey cost } \\
\text { estimates }\end{array}$ \\
\hline Irrigate with solid-set sprinklers & $142^{\mathrm{y}}$ & 128 \\
for crop establishment & $130^{\mathrm{x}}$ & \\
Irrigate with surface drip tape & $422^{\mathrm{w}}$ & 431 \\
& $439^{\mathrm{v}}$ & \\
\hline
\end{tabular}

${ }^{\mathrm{z}} \$ 1.00 /$ acre $=\$ 2.4611 / \mathrm{ha}$.

'Wilson et al. (2011).

xTourte and Smith (2010).

"Stoddard et al. (2006).

"Takele et al. (2013).

unstallation, material cost, irrigation and system inspection, maintenance, and removal.

$\mathrm{DR}$ and $\mathrm{OH}$, respectively). Tomato plant aboveground biomass accumulation in 2012 followed a pattern similar to canopy coverage estimates (Fig. 5). Irrigation had a significant effect $(P<0.05)$ on tomato biomass 


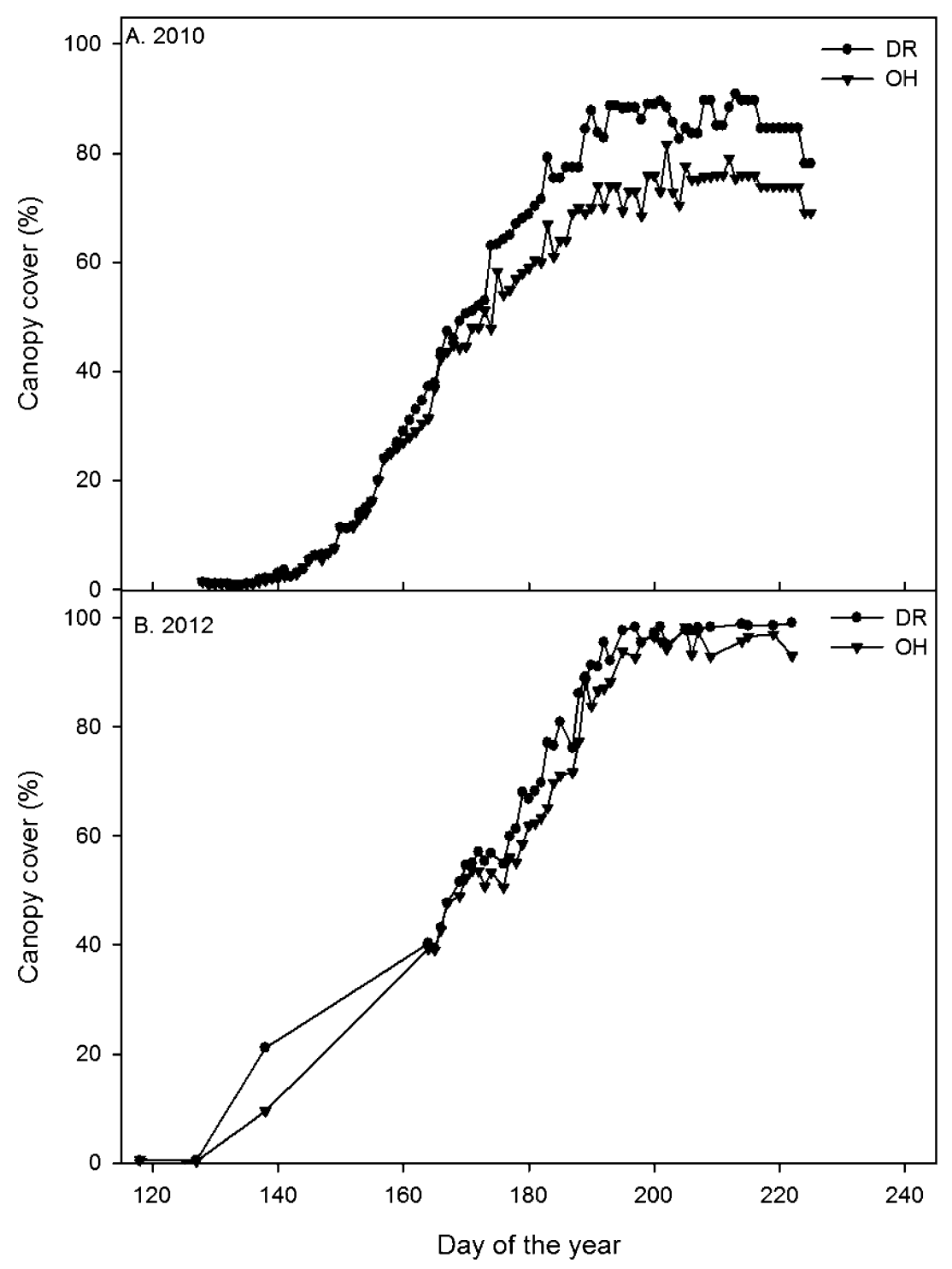

Fig. 3. Percent canopy cover for drip (DR) and overhead $(\mathrm{OH})$ irrigated tomato at Five Points, CA, in (A) 2010 and (B) 2012.

at several sampling dates. Throughout the entire first half of the measurement period, biomass accumulation was similar between the $\mathrm{DR}$ and $\mathrm{OH}$ treatments; however, during much of the last half of the season, biomass of the tomato plants was greater in the DR than in the $\mathrm{OH}$ system (Fig. 5). By the end of the growing season, there was about a 2.5 -fold increase in tomato biomass in the DR system relative to the $\mathrm{OH}$ system. These growth data, the percent canopy cover data for both years, and the tomato fruit data for 2012 (Fig. 6) indicate that the $\mathrm{OH}$ tomato plants had similar early season growth compared with the DR plants, but from a point early in the rapid- to mid-vegetative growth phase, their growth slowed and particularly in
2010 , did not catch up with the DR plants.

Tomato yield was greater in 2012 than in 2010 [ $P=0.001$ (Fig. 7)]. Tomato yield averaged over both irrigation systems was 38\% (20 tons/ acre) greater in 2012 than in 2010 . Averaged over the 2 years, tomato yields were $48 \%$ (22 tons/acre) higher with the DR than with the $\mathrm{OH}$ system $(P=0.001)$.

The average soluble solids concentration of harvested red fruit in 2010 was $5.99 \%$ for the DR system and $6.65 \%$ for the $\mathrm{OH}$ system $(P=0.03)$. These data provide further evidence that the $\mathrm{OH}$ tomatoes were water stressed as late-season water deficits are known to increase fruit solids (Hanson and May, 2005; Mitchell et al., 1991). Fruit pH did not differ between irrigation treatments with the DR tomatoes having a $\mathrm{pH}$ of 4.42 and the $\mathrm{OH}$ fruit a $\mathrm{pH}$ of 4.49 .

The severe yield reductions in the $\mathrm{OH}$ systems relative to the DR treatments warrant further consideration so that improved management regimes may be developed. Perhaps the most obvious explanation for the slower growth and lower tomato yields in the $\mathrm{OH}$ system is related to the possibility that the water-use efficiency, defined as the ratio of yield to $\mathrm{ETc}$, of the $\mathrm{OH}$ systems was lower due to higher soil water evaporation losses relative to productive water flow via crop transpiration (Sposito, 2013). In crop production, because water that is transpired contributes to plant function and growth, whereas water that is lost directly from the soil via evaporation brings little functional value to production, reducing the $\mathrm{E}$ component of ET is a means for increasing overall crop water-use efficiency, which was higher in the DR systems.

In studies comparing subsurface drip-irrigated tomato with furrowirrigated tomato, Hanson and May (2006) pointed out that evaporation under subsurface DR may be less than under furrow irrigation particularly during the early growth stages when spikes in ETc occur, due presumably to evaporation from wetting of the soil surface across the bed width as occurs in surface or full-cover sprinkler applications. The authors indicated that cumulative ETc at the end of the canopy development was 4.6 inches more for the furrow system than for the subsurface DR system, presumably due to soil water evaporation, or "nonproductive flow." The efficiency of sprinkler irrigation declines when applied water evaporates from the wetted canopy and from the soil surface before it is used by the crop as transpiration (Thompson et al., 1997; Tolk et al., 1995). However, total sprinkler application evaporation losses are also known to be lowered because of suppression of crop transpiration due to canopyintercepted water and microclimate modification (Stambouli et al., 2013; Tolk et al., 1995). Thus, field water balance measurements have shown that net sprinkler evaporation losses range from $5.1 \%$ to $7.1 \%$ of applied irrigation water of corn [Zea mays 


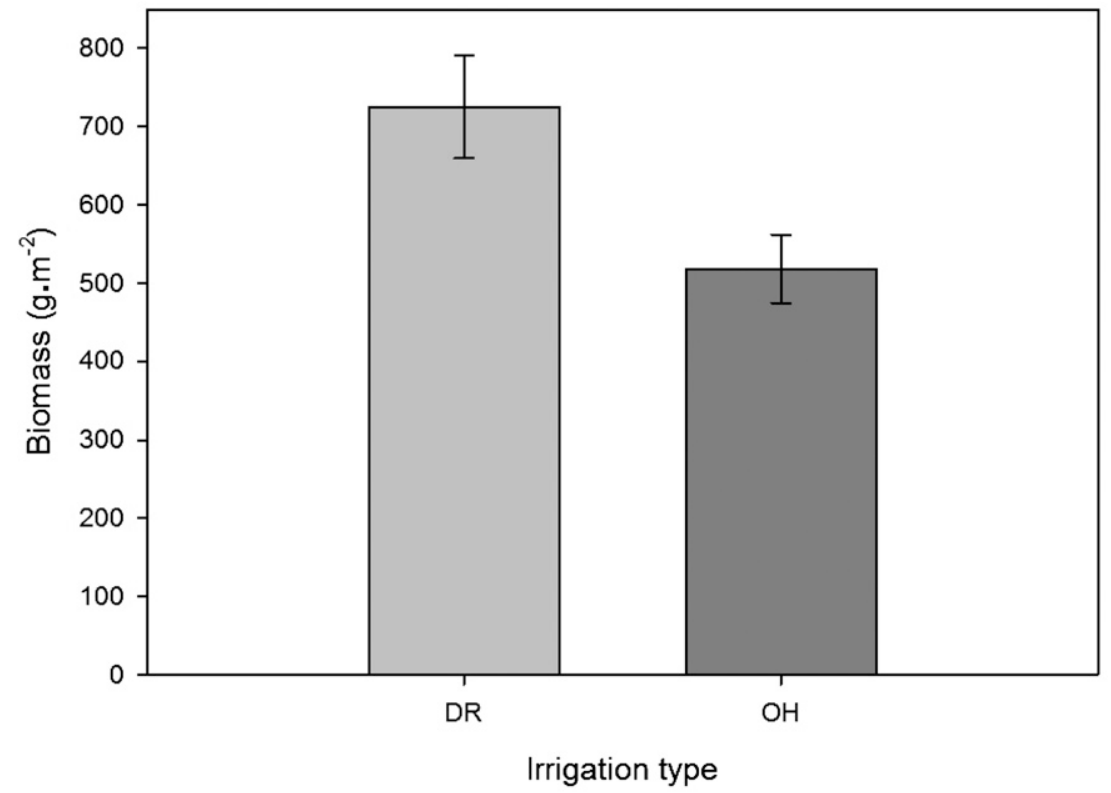

Fig. 4. Aboveground tomato plant biomass dry weight for 10 July 2010 for drip (DR) and overhead $(\mathrm{OH})$ irrigation systems at Five Points, CA; $1 \mathrm{~g} \cdot \mathrm{m}^{2}=0.0033 \mathrm{oz} / \mathrm{ft}^{2}$.

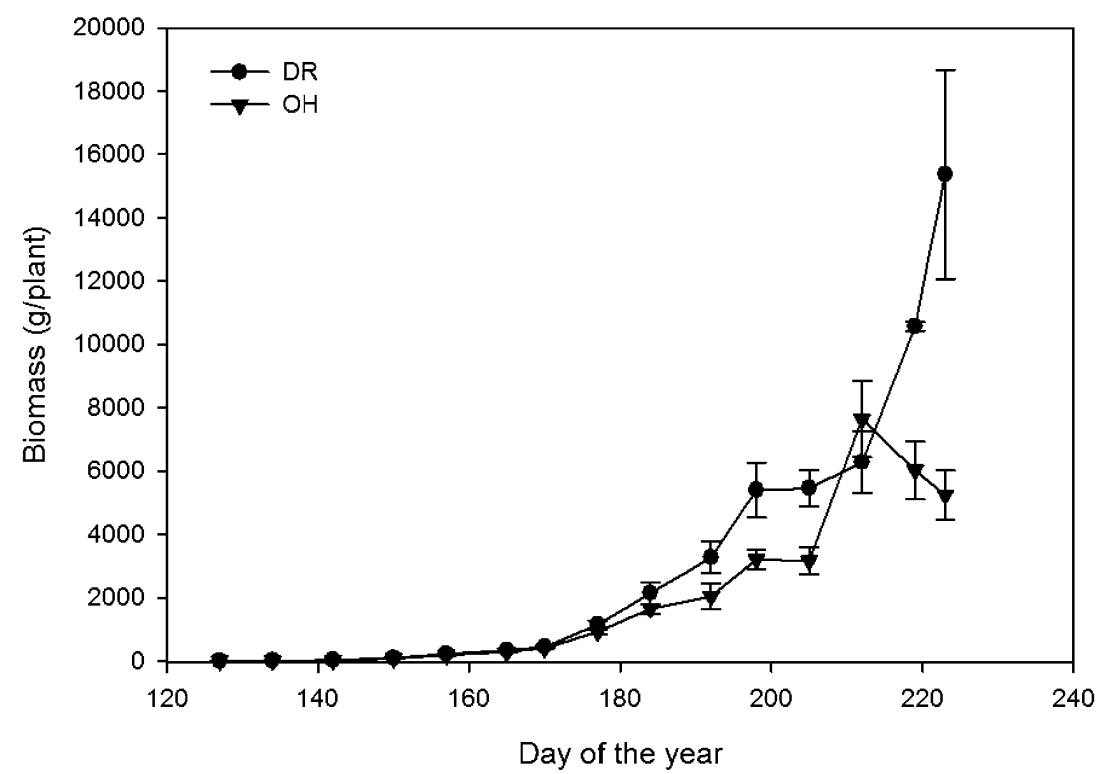

Fig. 5. Aboveground tomato plant biomass dry weight for four plants in drip (DR) and overhead $(\mathrm{OH})$ irrigated systems at Five Points, CA, in $2012 ; 1 \mathrm{~g}=0.0353 \mathrm{oz}$.

(Tolk et al., 1995)], to $\approx 9.8 \%$ during the day and $5.4 \%$ at night for alfalfa [Medicago sativa (Stambouli et al., 2013)]. In our studies, we tried to minimize these losses by use of the "bubbler" or low elevation precision application nozzles with their reduced wetting area application patterns early and late season. However, there were periods during the season in both years when higher levels of evaporation occurred from bare soil in the $\mathrm{OH}$ system relative to the $\mathrm{DR}$ system particularly because of the relatively high number of $\mathrm{OH}$ irrigations that were applied in these studies. Increasing the volume of applied water and thereby reducing the number of irrigations during a season is known to reduce the overall percentage of evaporation losses and would be a means for improving the wateruse efficiency of the $\mathrm{OH}$ system (Jasa, 2014). The following example illustrates this point. When sprinkler irrigation occurs over a crop canopy, an inevitable percentage of the applied water captured by the canopy and stored in the uppermost soil surface level is subject to evaporation loss and does not become part of the crop's direct transpiration stream through the soil-plant-atmosphere continuum (Philip, 1966). This "interception storage" (F. Lamm, personal communication) has been determined to be about 0.10 inches for a crop such as corn (Thompson et al., 1997) and represents in general, a loss of water. If a 0.5 -inch sprinkler irrigation is applied, this 0.10 -inch loss to intercepted storage is a $20 \%$ loss of the total applied water. However, if a 1.0 -inch irrigation is applied, the loss to evaporation is only $10 \%$. Therefore, in a practical sense, best management practice for $\mathrm{OH}$ involves applying the largest sprinkler irrigation possible that matches the soil's instantaneous infiltration rate and avoids runoff so as to minimize evaporative losses if this phenomenon is not accounted for or loss made up, growth and yield reductions may be expected.

A second factor that may have contributed to the lower yields in the $\mathrm{OH}$ system is that no "preirrigation" or root zone soil water replenishment was done before either of the cropping seasons. Irrigations were applied in accordance to customary practices in local commercial farms (S. Schmidt, personal communication) except for these preseason profile-recharging irrigations that are commonly used. Having the soil profile full at the beginning of the tomato season may have buffered, at least to some extent, against the midseason growth reduction and eventual yield losses that were observed in our study in the $\mathrm{OH}$ system. We attempted to account for the fact that no preirrigation was applied by increasing the amount of total water applied to both systems. However, in the case of the $\mathrm{OH}$ system, the timing or location of this applied water did not result in increased tomato growth and yield.

A final contributing factor to the lower yields of the $\mathrm{OH}$ system centers on how in-season liquid fertilizer was applied via the two irrigation systems. With the DR system, fertilizer applications were made directly to the root zone of the tomato plants where acquisition and uptake occur. However, in the $\mathrm{OH}$ system, fertilizers were applied 


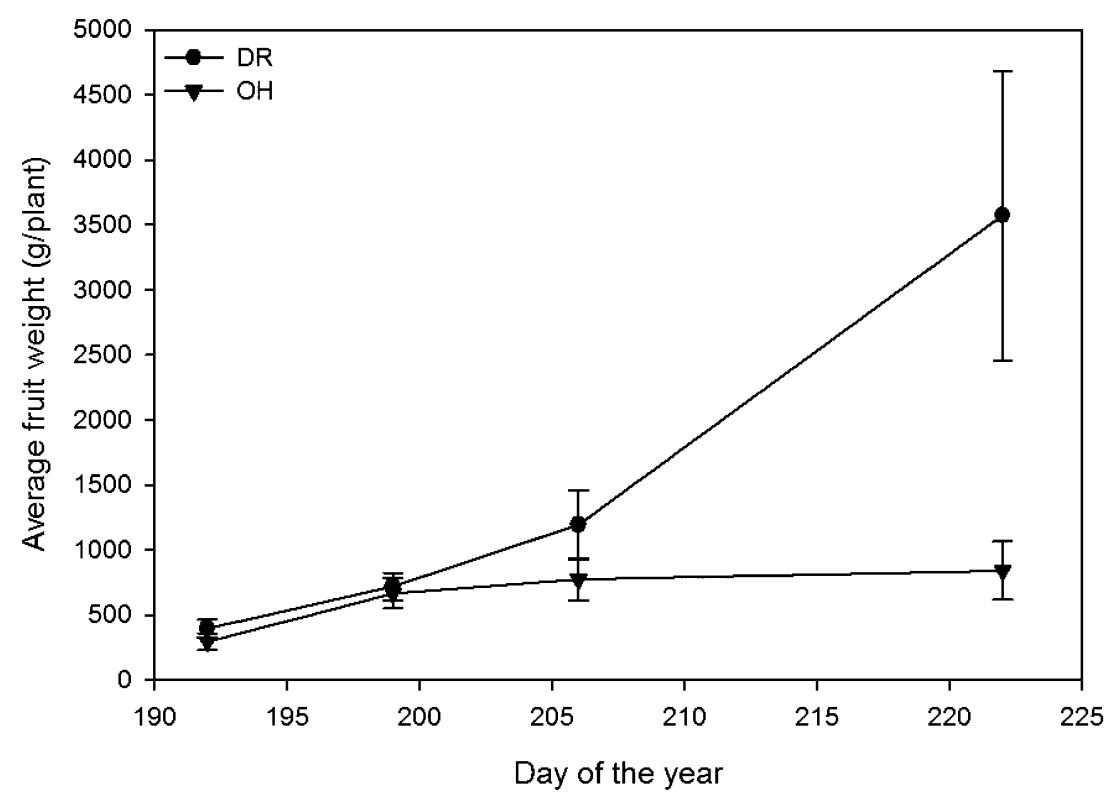

Fig. 6. Tomato fruit weights for 2012 for drip irrigation (DR) and overhead irrigation $(\mathrm{OH})$ systems at Five Points, CA; $1 \mathrm{~g}=0.0353 \mathrm{oz}$.

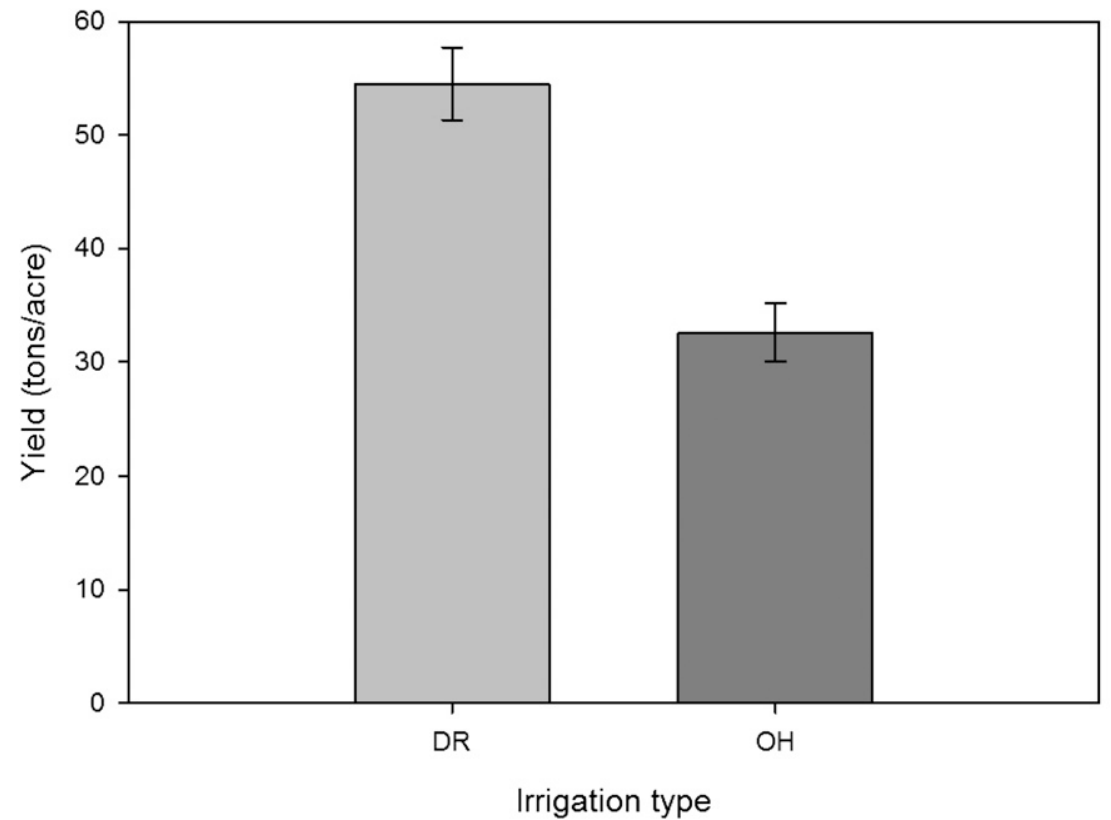

Fig. 7. Tomato red fruit yields (ton/acre) for overhead $(\mathrm{OH})$ and drip (DR) systems

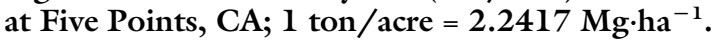

throughout the entire planting bed area including the furrow (Fig. 1) and we postulate that this more diffuse application method may have been a major contributing factor to both the restricted growth and the lower yields of this system that could be addressed by a variety of banded or otherwise more precise application methods. Monitoring plant nutrient status may also be a means for improving the performance of the $\mathrm{OH}$ system.
The cost for installing and removing solid-set sprinklers for crop establishment averaged $\$ 135$ per acre, and for installing and removing thin-walled surface or near-surface drip tape when rotating from a subsurface drip-irrigated tomato crop to a surface drip-irrigated crop such as onion or garlic assuming two lines of tape are sued for each 60 -inch bed were estimated to be $\$ 135$ per acre (Stoddard et al., 2006; Wilson et al., 2011 ) and $\$ 431$ per acre, respectively.
If yields between the subsequent crop are assumed to be equal between the $\mathrm{DR}$ and $\mathrm{OH}$ systems and if average yields of 55.7 tons/acre are attained with an average return of $\$ 69$ per ton, then a farmer would need to achieve tomato yields of $85 \%$ or more with the $\mathrm{OH}$ system relative to the DR system to match returns on investment of the surface DR system (Fresno County Department of Agriculture, 2012) The challenge to overcome the lower yields that are reported here for the $\mathrm{OH}$ system is thus warranted; however, due to these, savings in cost and labor that may be afforded by $\mathrm{OH}$ systems and may be guided by the findings of this study.

\section{Literature cited}

Arroues, K.D. 2006. Soil Survey of Fresno County, California, Western Part. 29 June 2012. 1 Apr. 2014. <http://soildatamart. nrcs.usda.gov/Manuscripts/CA653/0/ fresno.pdf>.

California Irrigation Management Information System. 2012. CIMIS Overview. 1 Apr. 2014. <http://wwwcimis.water. ca.gov/>

Fresno County Department of Agriculture. 2012. Annual Crop \& Livestock Report 2012. 1 Apr. 2014. <http://www.co.fresno. ca.us/WorkArea/DownloadAsset.aspx?id = $55145>$.

Geisseler, D. and W.R. Horwath. 2013. Production of processing tomatoes in California. In Assessment of plant fertility and fertilizer requirements for agricultural crops in California. 1 Apr. 2014. <http:// apps.cdfa.ca.gov/frep/docs/Tomato_ Production_CA.pdf $>$.

Hanson, B.R. and D.M. May. 2005. Crop coefficients for drip-irrigated processing tomato. Agr. Water Mgt. 81:381-399.

Hanson, B.R. and D.M. May. 2006. New crop coefficients developed for high-yield processing tomatoes. Calif. Agr. 60:95-99.

Hanson, B.R., D.M. May, and L.J. Schwankl. 2003. Effect of irrigation frequency on subsurface drip irrigated vegetables. HortTechnology 13:115-120.

Hartz, T.K., G. Miyao, J. Mickler, M. LeStrange, S. Stoddard, J. Nunez, and B. Aegerter. 2008. Processing tomato production in California. Univ. California, Div. Agr. Natural Resources Publ. 7228.

Jasa, P. 2014. Conserving soil and water with cover crops and crop residues. 1 Apr. 2014. <http://expertise.unl.edu/profile. xhtml? profile $=184>$. 
Johnson, B., C. Thompson, A. Giri, and S. Van NewKirk. 2011. Nebraska irrigation fact sheet. Univ. Nebraska Dept. Agr. Econ. Rpt. No. 190. 1 Apr. 2014. <http://agecon.unl.edu/c/document library/get_file?uuid = a9fcd902-4da9-4c3f9 e $04-\mathrm{c} 8$ b 56 a 9 b 22 c 7 \&groupId = 2369805\&.pdf>.

Mitchell, J.P., C. Shennan, and S.R. Grattan. 1991. Developmental changes in tomato fruit composition in response to water deficit and salinity. Physiol. Plant. 83:177-185.

Mitchell, J.P., Klonsky, K.M., E.M. Miyao, and K.J. Hembree. 2009. Conservation tillage tomato production in California's San Joaquin Valley. Univ. California, Div. Agr. Natural Resources Publ. 8330.

Mitchell, J.P., K.M. Klonsky, E.M. Miyao, B.J. Aegerter, A. Shrestha, D.S. Munk, K.J. Hembree, N.M. Madden, and T. Turini. 2012. Evolution of conservation tillage systems for processing tomato in California's Central Valley. HortTechnology 22:1-10.

Pelter, G.Q. and E.J. Sorensen. 2003. Crop Profile for Onions in Washington. 1 Apr. 2014. <http://www.ipmcenters. org/cropprofile/docs/waonions.html>.

Phene, C.J. 2010. Drip irrigation can reduce California's water application by $2.4 \times 10^{6}$ ac$\mathrm{ft}$ per year without yield reduction. Proc. 5 th Natl. Decennial Irr. Conf. p. 1-28.
Phene, C.J., R.L. McCormick, and J.M. Miyamoto. 1985. Evapotranspiration and crop coefficient of trickle-irrigated tomatoes. Proc. Third Intl. Drip/Trickle Irr. Congr. Drip/Trickle Irrigation in Action. 18-21 Nov. 1985. Fresno, CA. p. 823-831.

Philip, J.R. 1966. Plant water relations: Some physical aspects. Annu. Rev. Plant Physiol. 17:245-268.

Sposito, G. 2013. Green water and global food security. Vadose Zone J., doi: 10.2136/vzj2013.02.0041.

Stambouli, T., A. Martinez-Cob, J. Maria Faci, T. Howell, and N. Zapata. 2013. Sprinkler evaporation losses in alfalfa during solid-set sprinkler irrigation in semiarid areas. Irr. Sci. 31:1075-1089.

Stoddard, C.S., K.M. Klonsky, and R.L. DeMoura. 2006. Sample costs to produce sweet potatoes. Univ. California Coop. Ext. PO-SJ-06.

Takele, E., O. Daugovish, and M. Vue. 2013. Costs and profitability analysis for celery production in the Oxnard Plain, Ventura County, 2012-2013. Univ. California Coop. Ext., Ventura, CA.

Thompson, A.L., D.L. Martin, J.M. Norman, J.A. Tolk, T.A. Howell, J.R. Gilley, and A.D. Schneider. 1997. Testing of a water loss distribution model for moving sprinkler systems. Trans. Amer. Soc. Agr. Eng. 40:81-88.
Tolk, J.A., T.A. Howell, J.L. Steiner, D.R. Krieg, and A.D. Schneider. 1995. Role of transpiration suppression by evaporation of intercepted water in improving irrigation efficiency. Irr. Sci. 16:89-95.

Tourte, L. and R. Smith. 2010. Sample production costs for wrapped iceberg lettuce Sprinkler irrigated-40-inch beds. 2010. Univ. California Coop. Ext. LT-CC-10.

U.S. Department of Agriculture. 2007. Census of Agriculture. Volume 3. Special Studies. Part 1. Farm and Ranch Irrigation Survey (2008). AC-07-SS-1. 1 Apr. 2014. <http:// www.agcensus.usda.gov/Publications/ 2007/Online_Highlights/Farm_and_ Ranch_Irrigation_Survey/fris08.pdf $>$.

U.S. Department of Agriculture. 2014. Tomatoes. 1 Apr. 2012. <http://www.ers.usda. gov/topics/crops/vegetables-pulses/ tomatoes.aspx>.

Wilson, R., W. Riggs, K.M. Klonsky, P. Livingston, and R.L. DeMoura. 2011. Sample costs to produce onions for dehydrating. Univ. California Coop. Ext. ONIR-11. 